\title{
The Relationship between Credit Volume and Current Account Deficit: A Dynamic Analysis for Turkey ${ }^{1}$
}

\author{
Pinar KARAHAN ${ }^{2}$ Nilgün ÇAĞLARIRMAK USLU ${ }^{3}$ \\ Received:23/02/2016; Revised:12/05/2016; Accepted:20/05/2016
}

\begin{abstract}
One of Turkey's most important macroeconomic problems is persistent current account deficit. Credit volume has been shown as one of the basic determinants of current account rate, especially after the global financial crisis in Turkish economy. The Central Bank of Turkey has begun to implement the policy to ensure financial stability by slowing down credit volume in response to current account deficit affected by rapid credit expansion after the global financial crisis of 2008. In this study, we investigated the relationship between credit volume and current account deficit covering the period of 2005:Q1- 2015:Q3 employing Bound test approach, ARDL model and Kalman filter method. Bound test results suggest the existence of co-integration relationship between current account deficit and credit volume. ARDL model results indicate that the credit volume is statistical significant and positively affects current account deficit in the short and long run. The results show that a $1 \%$ increase in credit volume leads to nearly a $0.62 \%$ increase in current account deficit. Kalman Filter method results indicate that the effect of credit volume on current account deficit increased after global financial crisis and started to decrease after 2013.
\end{abstract}

Keywords: Current Account Deficit, Credit Volume, Kalman Filter.

JEL Codes: E42, E51, F32, C32.

\footnotetext{
${ }^{1}$ The paper was presented at the EconWorld 2016 conference held at London, England, August, 10-12, 2016.

${ }^{2}$ Corresponding Author, Dr.E-mail: pkarahan@ anadolu.edu.tr

${ }^{3}$ Associate Professor, Department of Economics, Anadolu University ncaglarirmak@anadolu.edu.tr
} 


\section{Introduction}

During the global financial crisis, the excess liquidity caused by the expansionary monetary policy implements of the developed countries gave rise to capital inflows into Turkey, Turkish Lira appreciated and market interest rates dropped. (Central Bank of the Republic of Turkey (CBRT), 2010: 22). Following these, accelerated credit growth and increased import levels caused current account deficit to widen rapidly. (CBRT, 2011-I: 1).

Current accounts deficit, was 20.1 billion dollars in 2005, rose to 37 billion dollars in 2007 and to 44.4 billion dollars in 2010 and consequently CBRT started to apply a policy that considers price stability as well as financial stability since the end of 2010. For this purpose, CBRT increased reverse requirement ratios while decreasing policy interest rates. In order to depress the credit growth rate, Banking Regulation and Supervision Agency (BRSA) increased the minimum payment amount of credit cards according to their limits and limited house loans to be provided by $75 \%$ of the value of the house.

Figure 1 displays the Current Account Deficit/GDP rate between 2003:Q1-2016:Q2 by years. Before the economic crisis, capital inflows and credit expansion increase, therefore current accounts deficit increases as well. However, during the years of crisis, balance of current accounts gets better as a result of capital outflows and credits narrow. After the years of crisis, same circumstances as the years before the crisis can be observed. (Saçik and Karaçayır, 2014: 1) In Figure 1, it can be seen that current account deficit/GDP significantly increased before the 2008 global financial crisis, decreased during the years of crisis and increased again after 2009:Q4. Ratio of current accounts deficit to GDP increased considerably from 2009:Q4 until 2011:Q4, and tended to decrease after CBRT started to apply the monetary policy strategy that respected the financial stability as well.

\section{Figure 1: Ratio of Current Account Deficit to GDP (\%)}

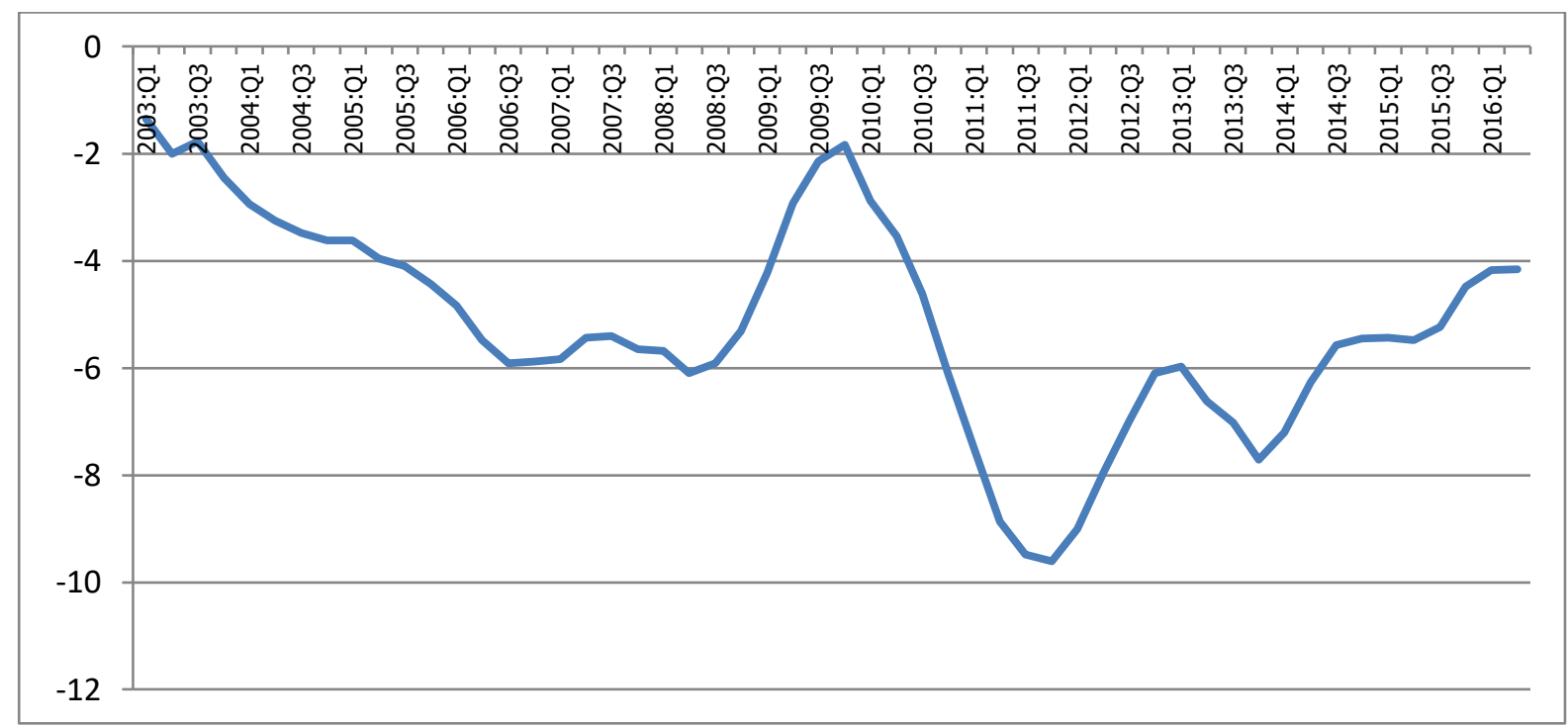

Source: CBRT (2016)

In this study, dynamic effects of credits on current account deficit will be analyzed and the importance of credits as the determinants of current account deficit will be shown. In the second section of the study, the former studies carried out concerning the relation between current deficit and credits will be analyzed. The third section presents the data set and the methodology and the last section has the findings of the analysis. 


\section{Literature Review}

Table 1 demonstrates the summary of some studies which investigated relationship between current account deficit and credit. According to Table 1, the studies for Turkish economy have been investigated the causality relationship between current account deficit and credit. Considering the literature, there is no general consensus about which loan type, such as, cash, commercial, house and automobile, has the biggest effect on current account deficit.

Table 1: Literature Summary on Current Account Deficit and Credit

\begin{tabular}{|c|c|c|c|c|}
\hline $\begin{array}{c}\text { Researcher / } \\
\text { Date of } \\
\text { Publication }\end{array}$ & $\begin{array}{r}\text { Analyzed } \\
\text { Country }\end{array}$ & The Period & The Method & Obtained Findings \\
\hline $\begin{array}{l}\text { Alioğulları et } \\
\text { al. (2015) }\end{array}$ & Turkey & $\begin{array}{l}\text { 2003:Q2- } \\
\text { 2015:Q2 }\end{array}$ & Regression & $\begin{array}{l}\text { It was determined that even though } \\
\text { effect of growing consumer loan on } \\
\text { current account balance is statistically } \\
\text { significant and negative, growing } \\
\text { commercial loan has no meaningful } \\
\text { effect on current account balance. }\end{array}$ \\
\hline $\begin{array}{l}\text { Atış and } \\
\text { Saygılı (2014) }\end{array}$ & Turkey & $\begin{array}{l}\text { 1998:01- } \\
\text { 2013:01 }\end{array}$ & $\begin{array}{l}\text { VECM and } \\
\text { Granger } \\
\text { Causality }\end{array}$ & $\begin{array}{l}\text { The results of the analysis determined } \\
\text { that there is a long-term relationship } \\
\text { between current account deficit and } \\
\text { credits and there is a one-way relation } \\
\text { of causality from credits to current } \\
\text { account deficit. }\end{array}$ \\
\hline $\begin{array}{l}\text { Göçer et al. } \\
(2013)\end{array}$ & Turkey & $\begin{array}{l}\text { 1992:Q1- } \\
\text { 2012:Q3 }\end{array}$ & $\begin{array}{l}\text { Cointegration } \\
\text { Test With } \\
\text { Multiple } \\
\text { Structural } \\
\text { Breaks of } \\
\text { Maki (2012) } \\
\end{array}$ & $\begin{array}{l}\text { It was determined that } 100 \% \text { increase } \\
\text { in domestic credit volume increases } \\
\text { current account deficit by } 20 \% \text { and that } \\
\text { credits are the leading determinant for } \\
\text { the process of current account deficit. }\end{array}$ \\
\hline $\begin{array}{l}\text { Sandalcılar } \\
\text { and Altıner } \\
(2014)\end{array}$ & Turkey & $\begin{array}{l}\text { 2003:Q1- } \\
\text { 2013:Q2 }\end{array}$ & $\begin{array}{l}\text { Granger } \\
\text { Causality }\end{array}$ & $\begin{array}{l}\text { In this study, although a relationship of } \\
\text { causality has been determined between } \\
\text { total credits, consumer loans and house } \\
\text { loans, there is no relationship of } \\
\text { causality determined between cash } \\
\text { loan, automobile loans and current } \\
\text { account deficit. }\end{array}$ \\
\hline Kılıç (2015) & Turkey & $\begin{array}{l}\text { 2004:Q4- } \\
\text { 2014:Q3 }\end{array}$ & $\begin{array}{c}\text { Engle Granger } \\
\text { Cointegration } \\
\text { And Granger } \\
\text { Causality }\end{array}$ & $\begin{array}{l}\text { In this study where cointegration } \\
\text { relationship was determined between } \\
\text { current account deficit and total } \\
\text { consumer loans, automobile loans, cash } \\
\text { loans and individual credit cards; there } \\
\text { has been relationship of causality } \\
\text { determined towards current account } \\
\text { deficit from mentioned series, except } \\
\text { for individual credit cards. }\end{array}$ \\
\hline Telatar (2011) & Turkey & $\begin{array}{l}\text { 2003:I- } \\
\text { 2010:IV }\end{array}$ & $\begin{array}{l}\text { Granger } \\
\text { Causality }\end{array}$ & $\begin{array}{l}\text { It was determined that there is a } \\
\text { positive relationship of causality from } \\
\text { consumer loans towards current } \\
\text { account deficit but there is no } \\
\text { relationship of meaningful causality } \\
\text { from total loans towards current } \\
\text { account deficit. }\end{array}$ \\
\hline
\end{tabular}

Source: Authors' own elaboration 
Table 1 (continuing): Literature Summary on Current Account Deficit and Credit

\begin{tabular}{|c|c|c|c|c|}
\hline $\begin{array}{l}\text { ToganveBeru } \\
\text { ment (2011) }\end{array}$ & Turkey & $\begin{array}{l}\text { 1993:Q1- } \\
\text { 2010:Q4 }\end{array}$ & VAR Model & $\begin{array}{l}\text { It was determined that capital inflows } \\
\text { increases the ratio of current accounts } \\
\text { balance/GDP and the effect of } \\
\text { increasing reel credits on above- } \\
\text { mentioned ratio is quite limited. }\end{array}$ \\
\hline $\begin{array}{l}\text { Bitzis et al. } \\
(2008)\end{array}$ & Greece & $\begin{array}{l}\text { 1995:Q1- } \\
\text { 2006:Q4 }\end{array}$ & $\begin{array}{c}\text { Johansen } \\
\text { Cointegration } \\
\text { and VECM }\end{array}$ & $\begin{array}{l}\text { It was determined that the real factors } \\
\text { which increases current deficit in the } \\
\text { long run are financial liberalization and } \\
\text { growing credits which reflect the low } \\
\text { interest rates; and in the short term, the } \\
\text { same factors are the prices of oil and } \\
\text { freightage. }\end{array}$ \\
\hline $\begin{array}{l}\text { Aizenman and } \\
\text { Jinjarak } \\
(2014)\end{array}$ & 36 Country & $\begin{array}{l}\text { 2005:Q1 } \\
\text { 2012:Q4 }\end{array}$ & $\begin{array}{c}\text { Dynamic } \\
\text { Panel Estimate }\end{array}$ & $\begin{array}{l}\text { It was concluded that, before and after } \\
2008-2009 \text { financial crises, there is a } \\
\text { firm relationship between increase in } \\
\text { real estate value, credits growth and } \\
\text { current account deficit }\end{array}$ \\
\hline $\begin{array}{l}\text { Ganioğlu } \\
(2013)\end{array}$ & $\begin{array}{l}24 \text { Developed } \\
\text { Country, } \\
26 \text { Less } \\
\text { Developed } \\
\text { Country }\end{array}$ & 1970-2008 & $\begin{array}{l}\text { Panel Logit } \\
\text { Estimation } \\
\text { Technique }\end{array}$ & $\begin{array}{l}\text { It was determined that, in both } \\
\text { developed and developing countries, } \\
\text { current account deficit and credit } \\
\text { expansion increases the possibilities for } \\
\text { a financial crisis to occur. }\end{array}$ \\
\hline $\begin{array}{l}\text { Akbaş et al. } \\
(2013)\end{array}$ & G7 Countries & 1990-2011 & $\begin{array}{c}\text { Panel } \\
\text { Cointegration }\end{array}$ & $\begin{array}{l}\text { In this study where it was determined } \\
\text { that there is a two-way relation of } \\
\text { causality between current account } \\
\text { deficit and total loans, it was also } \\
\text { determined that there is a one-way } \\
\text { relation of causality from foreign direct } \\
\text { investments towards current account } \\
\text { deficit and total loans. }\end{array}$ \\
\hline
\end{tabular}

Source: Authors' own elaboration

\section{Data and Methodology}

The paper aims to investigate the relationship between credit volume and current account deficit in Turkey. The dependent variable is the real current account deficit and the independent variable consists of the real total credit given by commercial bank to private sector from the period 2005:Q1 to 2015:Q3. Current account deficit and credit volume series in the analyses were obtained from CBRT (2016). Current account deficit series were converted Turkish Lira by using US dollar and were included in the analysis as its absolute value. The series were seasonally adjusted by using the Tramo-Seats methodology. Credit volume and current account deficit measured in natural logarithms and were denoted as LKRD and LCA respectively.

We firstly analyzed stationary properties of the series by employing ADF (Augmented Dickey-Fuller), PP (Phillips-Perron) and $\mathrm{Ng}$-Perron tests in the empirical analysis. After determining stationary properties for the series, we investigated the existence of cointegration relationship between credit volume and current account deficit employing Bound Test developed by Pesaran et al. (2001). The short and long term static relationship between credit volume and current account deficit were analyzed by employing ARDL model 
(Autoregressive Distribution Lag). Lastly, the dynamic relations between the series were examined by employing the Kalman Filter model.

\subsection{Unit Root Test}

We firstly analyzed stationary properties of the series by employing ADF (Augmented Dickey-Fuller), PP (Phillips-Perron) and Ng-Perron test in the empirical analysis. The results of unit root tests are presented in Table 1.

For ADF and PP tests, the null hypothesis suggests that the series include unit root. For $\mathrm{Ng}$-Peron test, according to $\mathrm{MZ}_{\mathrm{a}}, \mathrm{MZ}_{\mathrm{t}}$ tests the null hypothesis indicates that the series have unit root and according to MSB and MPT tests the null hypothesis indicates that the series are stationary (Ertuğrul and Kenar, 2013).

Table 1 shows that both LCA and LKRD series are integrated of order I(1) according to $\mathrm{ADF}, \mathrm{PP}$ and Ng-Perron tests results. The calculated t statistics for the series are less than the critical values in their level forms, the null hypothesis cannot be rejected for both ADF and PP tests. For Ng-Peron test, the calculated t statistics for LKRD and LCA are less according to MZa and MZt tests and greater than the critical values according to MSB and MPT tests. The calculated $t$ statistics for LKRD and LCA are greater according to MZa and MZt tests and less according to MSB and MPT tests for the first difference of series. In brief, unit root tests results suggest that LKRD and LCA series are stationary after differencing.

\section{Table 1: Unit Root Test Results}



Source: Authors' own estimations

\subsection{Co-Integration Analysis}

After determining stationary properties for the series, we investigated the existence of cointegration relationship between credit volume and current account deficit employing Bound Test developed by Pesaran et al. (2001). For the Bound test analysis, we utilize the 
Unrestricted Error Correction model (UECM) where "p" represents number of lags and "i" represents trend variables, may be written as follows.

$$
\Delta L C A_{t}=a_{0}+a_{1 t+} \sum_{i=1}^{p} a_{2 i} \Delta L C A_{t-i}+\sum_{i=0}^{p} a_{3 i} \Delta \mathrm{LKRD}_{t-i}+a_{4} L C \mathrm{~A}_{t-1}+a_{5} \Delta \mathrm{LKRD}_{t-1}+u_{t}
$$

The null hypothesis for $\mathrm{F}$ test, which examines co-integration relationship, is proposed as $\mathrm{H}_{0}: \alpha_{4}=\alpha_{5}=0$ and calculated $\mathrm{F}$ statistics is compared with table bottom and upper critical levels in Pesaran et al. (2001). If the estimated F statistic is lower than the bottom critical level, the null hypothesis cannot be rejected. Inversely, if the estimated F statistic is above the upper critical level, there is a co-integration relationship between the series (Karagöl et al., 2007: 76). Table 2 demonstrates the bound test results.

Table 2: Bound Test Results

\begin{tabular}{|c|c|c|c|}
\hline \multirow{2}{*}{$\mathrm{K}$} & \multirow{2}{*}{ F statistics } & \multicolumn{2}{|c|}{ Critical Values at \%5 Significance Level } \\
\cline { 3 - 4 } & \multirow{2}{*}{11.83} & Bottom Bound & Upper Bound \\
\hline & & 6.56 & 7.30 \\
\hline
\end{tabular}

Source: Authors' own estimations

Note: $\mathrm{K}$ is the number of independent variable in equation (1). Critical values are get from Table $\mathrm{CI}(\mathrm{V})$ at Pesaran et al. (2001).

Considering Table 2, F statistics is higher than the upper bound of critical values, which implies that the null hypothesis $\left(\mathrm{H}_{0}: \alpha_{4}=\alpha_{5}=0\right)$ is to be rejected. Bound test results show the existence of co-integration relationship between credit volume and current account deficit.

\subsection{ARDL Model}

After detecting co-integration relationship, the short and long run relationships between credit volume and current account deficit are analyzed by employing ARDL model (Autoregressive Distribution Lag). For this purpose, we use the following ARDL model specifications.

$$
\begin{gathered}
\mathrm{LC} A_{t}=a_{0}+\sum_{i=1}^{m} a_{1 i} \mathrm{LCA}_{t-i}+\sum_{i=0}^{n} a_{2 i} \operatorname{LKRD}_{t-i}+u_{t} \\
\Delta \mathrm{LCA}_{t}=a_{0}+a_{1} \mathrm{ECM}_{t-1}+\sum_{i=1}^{m} a_{2 i} \Delta \mathrm{LCA}_{t-i}+\sum_{i=0}^{n} a_{3 i} \Delta \mathrm{LKRD}_{t-i}+u_{t}
\end{gathered}
$$

ECM (-1), which is the error correction term, is the one period lagged value of the error terms derived from the equilibrium relationship and shows the extent of the eliminated rate of the short-run disequilibrium in the long run (Karagölet al., 2007: 78). Table 3 show that the estimated short and long-run coefficients by employing ARDL $(1,2)$ model.

There are no serial correlation, heteroscedasticity, and misspecification problems in the ARDL model according to the diagnostic checks. The long-run coefficient, which is 0.397 obtained from the ARDL $(1,2)$ model is statistically significant. The long-run coefficient estimates suggest that a $1 \%$ increase in credit volume will lead to nearly a $0.62 \%$ increase in current account deficit. The error correction term, which is ECT(-1), is estimated as -0.602 , 
which means in the case of the discrepancies from the long-run equilibrium in short-run, the system would reach equilibrium about approximately at 6 months.

In sum, according to the results of the ARDL model, credit volume is significant and positively affects current account deficit in both short and long run.

Table 3. ARDL $(1,2)$ Model Long and Short-Run Parameter Estimations

\begin{tabular}{|c|c|c|}
\hline Variables & Coefficient & T statistics \\
\hline LCA (-1) & 0.397475 & 3.206282 \\
\hline LKRD & 4.060400 & 2.210425 \\
\hline LKRD (-1) & 1.800181 & 0.543107 \\
\hline LKRD (-2) & -5.484610 & -2.685485 \\
\hline C & 2.044592 & 0.957288 \\
\hline Diagnostic Checks & $0.093432[0.9110]$ \\
\hline$X^{2}$ BG & $0.000410[0.9840]$ \\
\hline$X^{2}$ WHITE & $0.093111[0.7621]$ \\
\hline Estimated Long-run Coefficients Using ARDL(1,2) Model \\
\hline LKRD & 0.623993 \\
\hline C & 3.393371 \\
\hline ECM (-1) Error Correction Term Using ARDL(1,2) Model \\
\hline
\end{tabular}

Source: Authors' own estimations

\subsection{Kalman Filter Method}

We employ Kalman Filter approach in order to investigate dynamic relationship between reel credit volume and reel current account deficit. The Kalman Filter model is presented in equation (4) and (5) below.

$$
\begin{aligned}
& \mathrm{LCA}_{\mathrm{t}}=\alpha_{0}+\alpha_{1, \mathrm{t}} \mathrm{LKRD}+\varepsilon_{\mathrm{t}} \\
& \alpha_{1, \mathrm{t}}=\alpha_{1, \mathrm{t}-1+v_{\mathrm{i}, \mathrm{t}}}
\end{aligned}
$$

where $\varepsilon_{\mathrm{t}}$ and vi,t are vectors of mean zero, Gaussian disturbances. The Kalman filter recursively estimates the parameters by updating the estimation with every additional observation (Ertuğrul ve Kenar, 2013: 89). The $\alpha_{1, t}$ coefficient in equation (4) indicates credit elasticity of current account deficit, which shows percentage chance in current account deficit in response to a one percentage chance in credit. The time-varying parameter (TVP) estimates for credit elasticity of current account deficit are shown in Figure 1.

Figure 2 shows that the effect of credit volume on current account deficit;

- increased in the period of 2005:Q3 - 2007:Q1,

- followed a fluctuating course in the period of 2007:Q1 - 20008:Q2,

- decreased in the period of 2008:Q2 - 2010:Q2,

- increased from the period of 2010:Q2 until 2012:Q1,

- followed a stable course between the first quarter of 2012 and the third quarter of 2012, -despite minor fluctuations, the above-mentioned effect increased between the third quarter of 2012 and the fourth quarter of 2013,

- despite minor increases, the effect decreased on the whole between the third quarter of 2013 and the third quarter of 2015. 
Figure 2: Time-Varying Parameter (TVP) Estimates Result SV1F



Source: Authors' own estimations

The TVP results conclude that the effect of domestic credit volume on current account deficit decreased during the period of global financial crisis. Even after the period, in which policy precautions were initiated in order to decrease credit growth in the last quarter of 2010, the credits continued to be the determinant factor on current deficit.

\section{Conclusion}

The paper aims to investigate that the relationship between credit volume and current account deficit. We, in this study, firstly analyzed stationary properties of the series by employing ADF (Augmented Dickey-Fuller), PP (Phillips-Perron) and Ng-Perron test in the empirical analysis. After determining stationary properties for the series, we investigated the existence of co-integration relationship between credit volume and current account deficit employing Bound test developed by Pesaran et al. (2001). According to Bound test results, calculated F statistics was higher than the upper bound of critical values. Bound test results suggest the existence of co-integration relationship between current account deficit and credit volume. After detecting co-integration relationship, the short and long term static relationship between the credit volume and current account deficit were analyzed by employing ARDL model (Autoregressive Distribution Lag). According to the results of the ARDL models, there was a positive and statistically significant relationship between the credit volume and current account deficit in both the short and long term. ARDL model result revealed that an increase of $1 \%$ in credit volume have caused an increase of $0.62 \%$ in current deficit in long run. In other words, credit volume is one of the main determinants of current account deficit in Turkish economy. Lastly, the dynamic relationship between the credit volume and current account deficit was examined by employing the Kalman Filter. The results show that the effect of credit volume on current account deficit has decreased during the global financial crisis. The effect of credit volume on current account deficit has not decreased after the monetary policy implements in 2010 until the third quarter of 2013. After current account deficit tended to decrease in 2013 , the effect of credits on current account deficit started to decrease in this period.

The results suggest that credits are an important macroeconomic variable as the determinant of current account deficit in Turkey. Especially cash loans, that are predominant in credits, may lead a strong effect of credits on current account deficit. Therefore, we 
conclude that bank dependent borrowers' debt levels should reduce and it should be implemented the policy, which aims to increase national savings, so that current account deficit decrease.

\section{References}

Akbaş, Y.E., Şentürk, M. and Sancar, C. (2013). Testing for Causality between the Foreign Direct Investment, Current Account Deficit, GDP and Total Credit: Evidence from G7, Panoeconomicus, 6. doi:10.2298/pan1306791a

Alioğulları, Z.H., Başkaya, Y.S., Bulut, Y.E. and Kılınç, M. (2015). Türkiye'de Tüketici ve Ticari Kredilerin Cari Açıkla İlişkisi, Central Bank of the Republic of Turkey (CBRT) Research Notes in Economics, 2015-19.

Atış, A.G. and Saygıl1, F. (2014). Türkiye'de Kredi Hacmi ve Cari Açık İlişkisi Üzerine Bir İnceleme, Business and Economics Research Journal, 5(4).

Aizenman, J. and Jinjarak, Y. (2014). Real Estate Valuation, Current Account and Credit Growth Patterns, Before and After The 2008-9 Crisis, Journal of International Money and Finance, 48 (2014). doi:10.1016/j.jimonfin.2014.05.016

Bitzis, G., Paleologos, J.M. and Papazoglou, C. (2008). The Determinants of the Greek Current Account Deficit: The EMU Experience, Journal of International and Global Economic Studies, 1(1).

CBRT (2016), Interactive Charts. http://www.tcmb.gov.tr/wps/wcm/connect/TCMB+TR/ TCMB+TR/Main+Menu/Para+Politikasi/Interaktif+Grafikler/Cari+islemler+dengesi (accessed on 12.05.2016)

CBRT, 2016, Electronic Data Delivery System (EDDS), evds.tcmb.gov.tr/index_en.html (accessed on 12.05.2016)

CBRT (2010), Financial Stability Report, 11, 1-70. CBRT: Ankara

CBRT (2011). Inflation Report-I, 1-138. CBRT: Ankara

Ertuğrul, H. M. and Kenar, A. (2013). "External Debt and GDP Relationship: A Dynamic Analysis for Turkey”. Trakya Üniversitesi İktisadi ve İdari Bilimler Fakültesi E-Dergi, 2(1), 78-94.

Ganioğlu, A. (2013). Rapid Credit Growth and Current Account Deficit as the Leading Determinants of Financial Crises, Leibniz Information Centre for Economics, Economics Discussion Papers, No. 2013-35.

Göçer, İ., Mercan, M. and Pek, O. (2013). Kredi HacmiArtışının Cari Açığa Etkisi: ÇokluYapısalKırılmalı Eşbütünleşme Analizi, İstanbul Üniversitesi, Ekonometri ve İstatistik Dergisi, 18.

Karagöl, E., Erbaykal, E. and Ertuğrul, H. M. (2007). Türkiye'de Ekonomik Büyüme ile ElektrikTüketimi İlişkisi: Sınır Testi Yaklaşımı. Doğuş Üniversitesi Dergisi, 8(1).

Kılıç, C. (2015). Tüketici Kredileri ve Cari Açık Arasındaki İlişki: Türkiye Örneği, Atatürk Üniversitesi İktisadi ve İdari Bilimler Dergisi, 29 (2). 
Narayan, P. K. and Narayan, S. (2005). Estimating Income and Price Elasticities of Imports for Fiji in a Cointegration Framework. Economic Modeling, 22, 423-438. doi:10.1016/j.econmod.2004.06.004

Sandalcılar, A.R. and Altıner, A. (2014). Türkiye'de Tüketici Kredileri İle Cari İşlemler Açı̆̆ıArasındaki Nedensellik İlişkisi. The Bank Association of Turkey (BAT), Bankacılar Dergisi, 89.

Telatar, E. (2011). Türkiye'de Cari Açık Belirleyicileri ve CariAçık-Krediler İlişkisi, The Bank Association of Turkey (BAT), Bankacilar Dergisi, 78.

Togan, S. and Berument H. (2011). Cari İşlemler Dengesi, Sermaye Hareketleri ve Krediler, The Bank Association of Turkey (BAT), Bankacilar Dergisi, 78. 